\title{
PREVENTIVNÍ ÚDRŽBA TRAMVAJOVÝCH SRDCOVEK S MĚLKÝM ŽLÁBKEM POMOCÍ NAVAŘOVÁNÍ
}

\author{
TRAMWAY SHALLOW CROSSING PREVENTIVE MAINTENANCE BY \\ SURFACE WELDING
}

\author{
Magdalena Křečková*,1 \\ ${ }^{*}$ magdalena.kreckova@fsv.cvut.cz \\ ${ }^{1}$ Fakulta stavební, ČVUT v Praze, Katedra železničních staveb, Thákurova 2077/7, Praha 6 - Dejvice, 16629
}

\begin{abstract}
Abstrakt
Příspěvek se zabývá problematikou preventivního navařování a údržby tramvajových srdcovek s mělkým žlábkem. Př́íspěvek představuje hlavní vlivy působící na vývoj ojetí a deformace srdcovek s mělkým žlábkem, které jsou charakteristické postupným úbytkem materiálu a změnou geometrie žlábků. Příspěvek předkládá prŕípadovou studii dlouhodobě sledované tramvajové srdcovky s mělkým žlábkem na lokalitě Praha - Výtoň, na které je demonstrován typický vývoj stavu žlábků srdcovky v čase až do času její preventivní údržby navařením a následný vývoj po provedené údržbě a jeho srovnání s původním stavem nové srdcovky. Př́íspěvek se dále blíže zaměřuje na samotný preventivní zásah navařením a reprofilaci žlábků během této preventivní údržby.
\end{abstract}

\section{Klíčová slova}

Mělká srdcovka, ojetí, deformace, navaření, reprofilace

\begin{abstract}
The article deals with the issue of preventive welding and maintenance of tramway shallow crossing. The article presents the main influences the development of head loss and deformation of shallow crossing which are characterized by gradual loss of material and change in the geometry of grooves. The article presents a case study of a long-term monitored tramway shallow crossing in the locality od Prague - Vyton which demonstrates typical development of condition of grooves of tramway shallow in time to its preventive maintenance by welding and next development after maintenance and its comparison with the original geometry of new tramway shallow. The article presents also preventive maintenance by surface welding and reprofiling grooves during this preventive maintenance.
\end{abstract}

\section{Key words}

Shallow crossing, head loss, deformation, surface welding, reprofiling

\section{1 ÚVOD}

Vlivem tramvajového provozu dochází k ojetí tramvajových srdcovek. Toto ojetí je charakteristické úbytkem materiálu a dochází tak jednak k rozšiřování žlábku, ale také k jeho prohlubování. Dále je toto ojetí charakteristické deformacemi dna žlábku, čímž vzniká jiný profil žlábku v srdcovce. Tyto změny tvaru vedou k údržbě srdcovky a k reprofilaci jejího žlábku.

Mělká tramvajová srdcovka, která se používá primárně v tramvajových výhybkových konstrukcích v Praze, je srdcovka, která má hloubku žlábku takovou, že je pojížděno dno žlábku okolky jednotlivých vozidel (v Praze se za mělké srdcovky považují srdcovky s hloubkou žlábku $14 \mathrm{~mm}$ ). To má za následek ojíždění srdcovky, a tedy úbytek materiálu, a dále vznik charakteristických deformací dna žlábku. Tyto deformace jsou závislé především na geometrii srdcovky - žlábek v odbočném směru má jiné charakteristické deformace než žlábek v přímém směru.

Pro žlábek v přímém směru je charakteristické jeho prohlubování a zaoblování hran žlábku a hran kř́idlovek. Pro žlábek v odbočném směru, tedy pro žlábek v oblouku, je charakteristické také jeho prohlubování. Nicméně dále dochází ke vzniku tzv. dvojžlábku - na dně žlábku vzniká vlivem pojíždění okolkem podélná hrana, která 
rozděluje žlábek na dvě části. Na následujícím obrázku jsou zobrazeny tyto charakteristické deformace na srdcovce v lokalitě Praha - Výtoň, která je v tomto ohledu charakteristická [1].

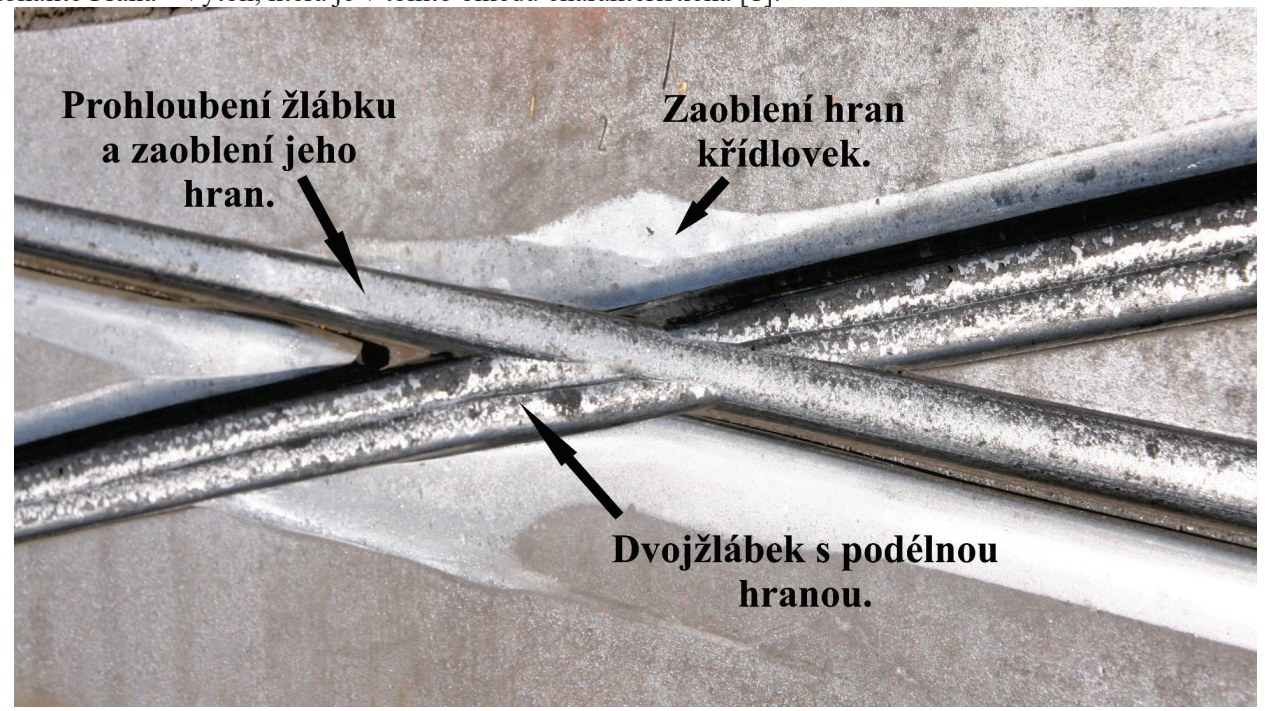

Obr. 1 Charakteristické deformace na srdcovce v lokalitě Praha - Výtoň (Zdroj: Autor).

Tyto deformace jsou viditelné také na následujícím grafu, který znázorňuje profil srdcovky za začátkem sjezdového hrotu srdcovky v průběhu času vč. dvou profilů již po údržbě navařením (profily z 16. 8. 2021 a 24. 9. 2021). V levé části grafu je znázorněn žlábek v přímém směru, v pravé části grafu je znázorněn žlábek v odbočném směru.

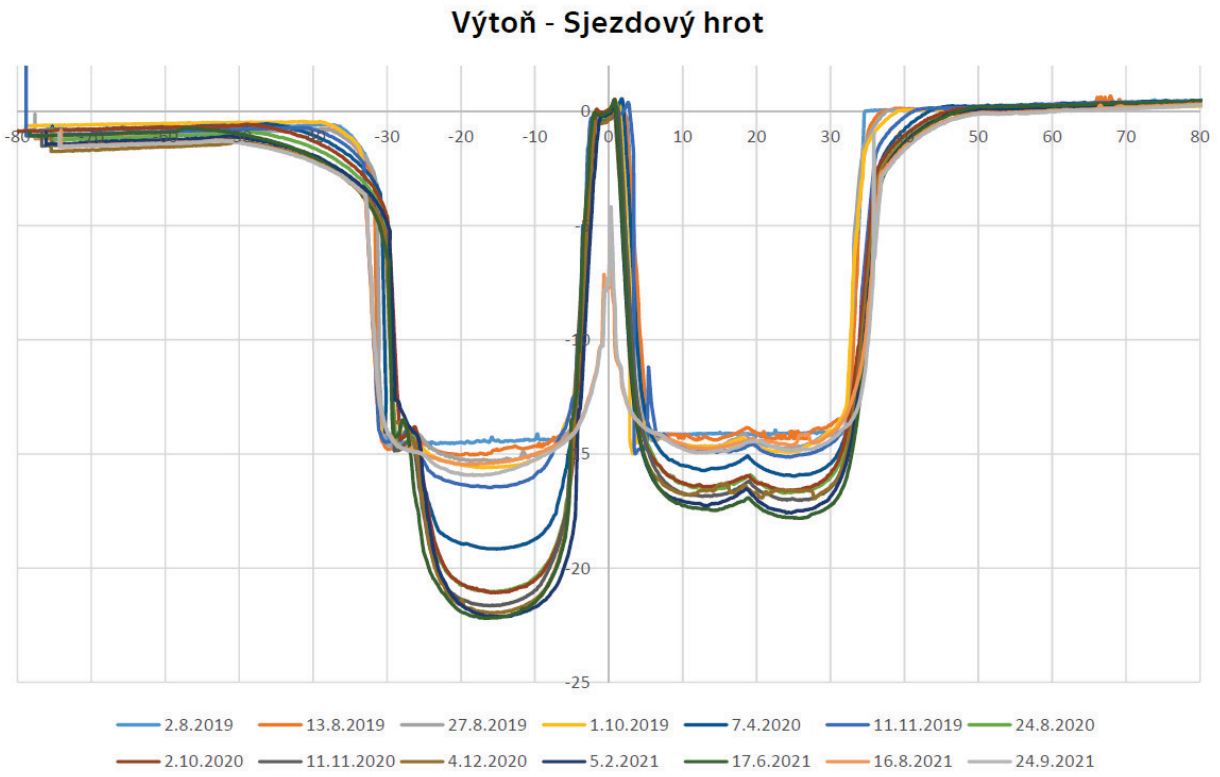

Obr. 2 Charakteristické deformace na srdcovce v lokalitě Praha - Výtoň v průběhu času(Zdroj: Autor).

\section{SOUČASNÝ STAV PROBLEMATIKY}

V tramvajové síti Dopravního podniku hlavního města Prahy se převážně využívají mělké srdcovky v kolejových konstrukcích s ohledem na charakter městského provozu, resp. s ohledem na úhel křížení kolejových konstrukcí. 
Použití mělké srdcovky (hloubka žlábku 14 mm), př́ípadně hluboké srdcovky, je tedy závislé na úhlu křížení. Prakticky se však mělká srdcovka používá pro všechny úhly křížení, protože v místě křížení je kolo převedeno přes srdcovku po okolku a není tedy omezeno přerušením kolejnice, resp. srdcovky. Nicméně vedení kola přes srdcovku po okolku má dále vliv na zhoršení směrového vedení kola a dále na deformace jak srdcovky, tak samotného kola. Dále je použití mělké srdcovky závislé na charakteru vozového parku Dopravního podniku hl. m. Prahy a to s ohledem na využívaný jízdní průřez kola, resp. s ohledem na šířku kola [2],[5]. Z těchto důvodů je tato problematika řešena především lokálně, a to především v provozu DP hl. m. Prahy.

U všech výhybek s mělkou srdcovkou dochází $\mathrm{k}$ dynamickému rázu při přechodu kola v místě křížení dále na rozjezdový hrot. Tyto rázy mají za následek zvýšení hlukových emisí v křižovatkách z kontaktu kola a kolejnice. Dále se tímto vlivem zvyšuje již zmíněné ojetí srdcovky a její deformace. Z těchto důvodů vyplývá snaha zavést systém preventivní údržby, která by měla za následek zvýšení životnosti tramvajových kolejových konstrukcí, snížení nákladů na údržbu a dále snížení emisí hluku vycházející právě z rázu při kontaktu kola a kolejnice. Této problematice se věnuje Projekt TAČR Dlouhodobý monitoring kolejových konstrukcí u tramvajových křižovatek, na kterém spolupracuje Fakulta stavební ČVUT v Praze, Pražská strojírna a.s. a Dopravní podnik hl. m. Prahy. V rámci tohoto projektu je tedy řešena i problematika preventivní údržby, a to především preventivním navařováním výhybkových konstrukcí a reprofilací žlábků srdcovky. Pro tento projekt bylo vybráno celkem 5 lokalit, nicméně jako charakteristická lokalita byla vybrána lokalita Praha - Výtoň, protože srdcovka této lokality reprezentuje jak deformace $\mathrm{v}$ př́mém žlábku, tak deformace $\mathrm{v}$ odbočném žlábku a také se jedná o poměrně zatíženou křižovatku (přibližně 38 spojů za hodinu) [5].

\section{METODIKA}

Jednotlivé lokality byly v rámci projektu nejdříve sledovány pomocí měřicího přístroje Contour II, který se využivá pro kontrolu ojetí kolejnic v tramvajové síti DPP zpravidla pro kontrolu ojetí v obloucích, pro kontrolu správného provedení návarů apod. Tento přístroj snímá povrch kolejových konstrukcí pomocí laseru a přenáší tvary jednotlivých příčných profilů do digitální podoby. Toto měření probíhá bud' kontinuálně nebo bodově. Kontinuální měření snímá povrch kolejnice v pravidelném kroku (v podélném profilu zpravidla 3,84 mm nebo 5,75 mm, v př́čném profilu $0,13 \mathrm{~mm}$ ) [1].

Následně byla tato data vyhodnocena pomocí softwaru Contour II - Eval. Při vyhodnocení byly vybrány vždy 3 charakteristické profily - sjezdový hrot srdcovky, střed srdcovky a profil rozjezdového hrotu srdcovky. Takto vyhodnocená data byla následně srovnána $\mathrm{v}$ průběhu času, čímž se docílilo znázornění vývoje deformací jednotlivých profilů v čase. V lokalitě Praha - Výtoň byla konstrukce sledována více než 2 roky. Při vyhodnocení stavu srdcovky jako kritického došlo k návaru a dále bylo provedeno další měření, které zachytilo další vývoj ojetí a deformací

\section{VÝSLEDKY}

\section{Vývoj deformací}

Vlivem tramvajového provozu došlo k postupnému ojetí srdcovky a ke vzniku charakteristických deformací. Pro potřeby tohoto př́spěvku byl vybrán profil ve středu srdcovky. Vývoj deformace a ojetí v tomto profilu jsou znázorněny na následujícím obrázku (Obr. 3).

Z tohoto znázornění deformace je evidentní, že dochází k prohlubování žlábku. Z původní hloubky nového žlábku $14 \mathrm{~mm}$ došlo během 15 měsíců $\mathrm{k}$ prohloubení na celkovou hodnotu 21,6 mm (první měření ze dne 2. 8. 2019 versus poslední měření před údržbou ze dne 17. 6. 2021). Dále je ze znázornění patrné, že došlo k zaoblení hran žlábku a to jak hran dna žlábku, tak hran v přechodu povrchu srdcovky (tzv. křídlovka) do žlábku. Toto zaoblení mělo také vliv na úbytek materiálu právě v místech přechodu z křídlovky do žlábku. Zde došlo k celkovému výškovému úbytku materiálu $3,8 \mathrm{~mm}$. Toto ojetí je vytvořeno především vlivem prohlubování dna žlábku, přičemž dochází ke snižování trajektorie pro okolek, čímž je namáhána křídlovka jízdní plochou kola.

\section{Navaření srdcovky}

V okamžiku, kdy došlo k vyhodnocení mezního stavu ojetí srdcovky, došlo k návaru srdcovky. Během tohoto procesu byl prưrezez žlábku reprofilován přidáním materiálu navařením. Srdcovka byla navařena tak, aby výsledná hloubka žlábku opět činila $14 \mathrm{~mm}$. Materiál se může na srdcovku přidávat dvěma způsoby: podélnými návarovými housenkami nebo příčnými návarovými housenkami. Podélné návarové housenky se provádějí rovnoběžně $\mathrm{s}$ hranami žlábku, resp. rovnoběžně se směrem jízdy. Proto je podélné navaření vhodnější vzhledem k dynamickým 
rázům při vedení okolku přes srdcovku. Nevýhodou podélného navaření je, že je časově náročnější pro provedení (housenky jsou dlouhé). Oproti tomu příčné návarové housenky jsou kratší, a tedy méně časově náročné na provedení. Nicméně vzhledem k tomu, že jsou př́ičné ke směru vedení okolku přes srdcovku, dochází kvưli nim $\mathrm{k}$ větším dynamickým rázům, což opět vede $\mathrm{k}$ většímu namáhání srdcovky a k větším hlukovým emisím. Vzhledem k tomu, že navařování srdcovek probíhá bez výluky za běžného nočního provozu, upřednostňuje se příčné navařování, protože neomezuje tramvajový provoz. Navařování srdcovky je znázorněno na Obr.4.

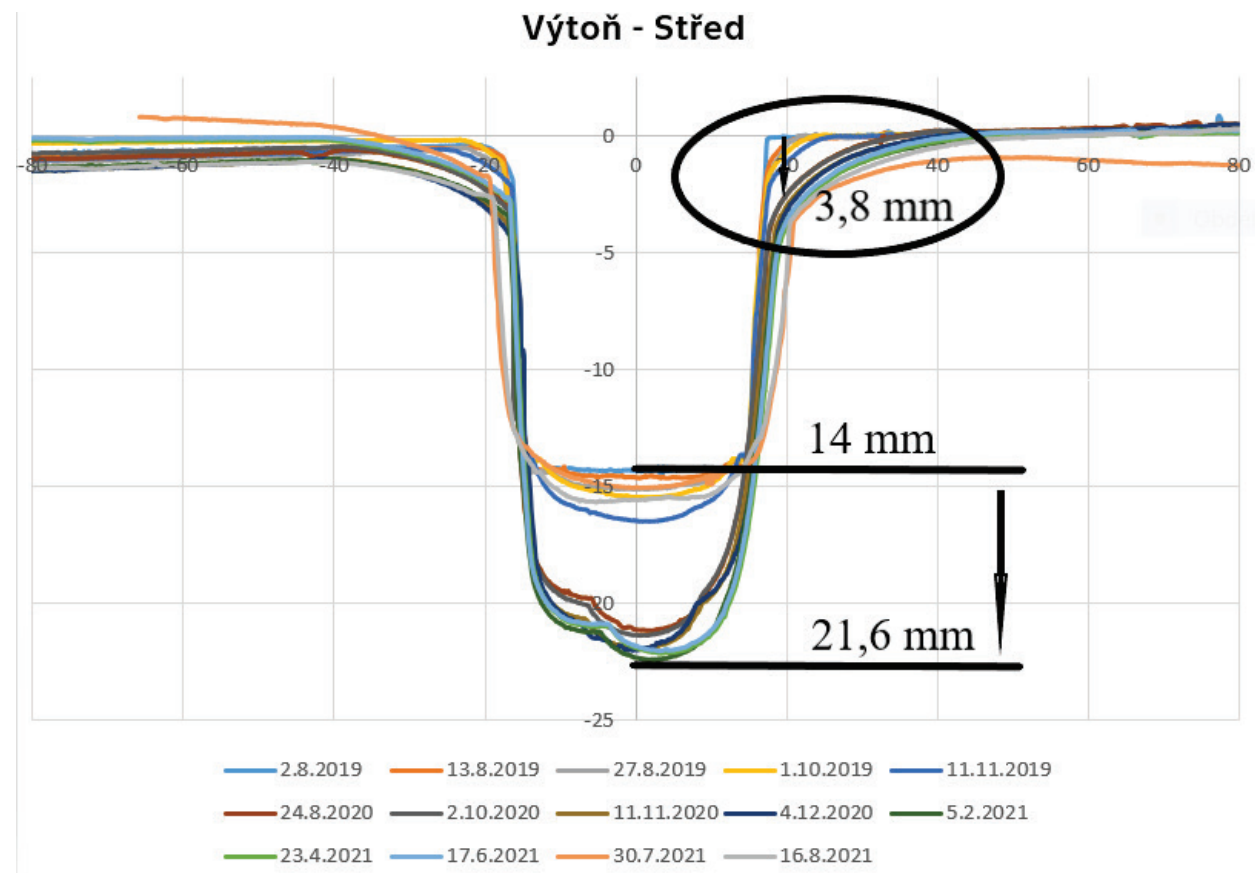

Obr. 3 Vývoj deformace v čase ve středovém profilu srdcovky v lokalitě Praha - Výtoň (Zdroj: Autor).

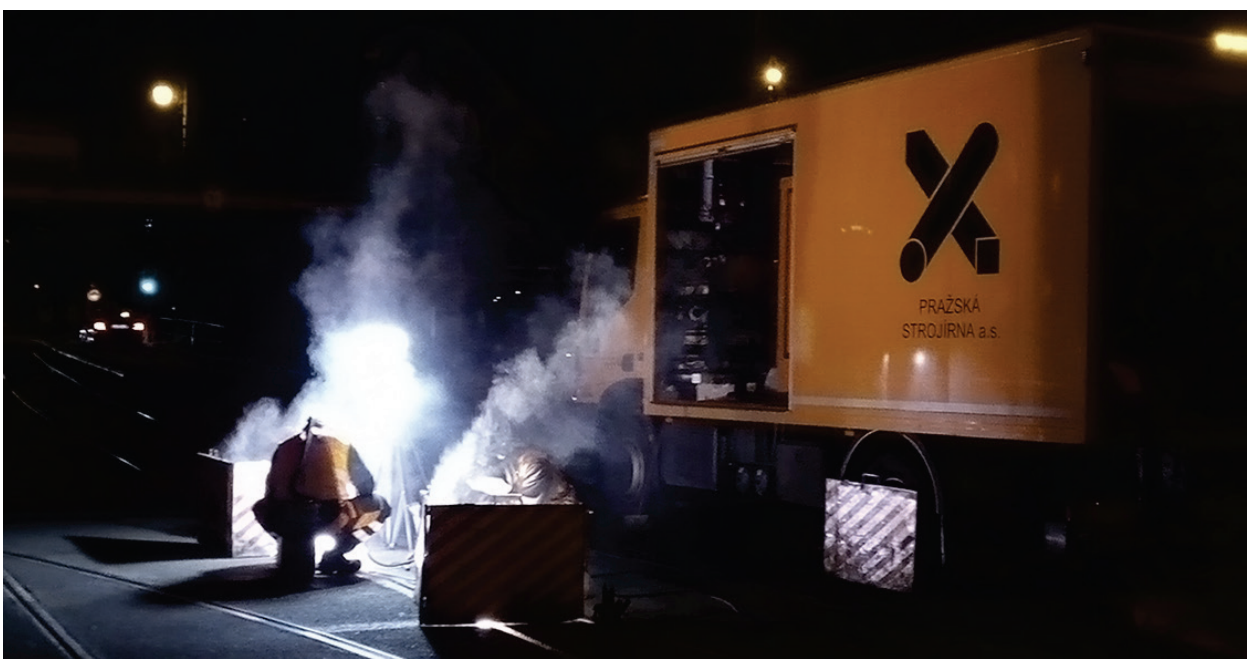

Obr. 4 Navařování tramvajové srdcovky v lokalitě Praha - Výtoň (Zdroj: Autor). Pro navaření se použila elektroda Weltrode 40. 


\section{DISKUZE}

Z celkového vývoje deformací byly vybrány 3 klíčové profily, které jsou zobrazeny na Obr.5. První profil znázorňuje tvar nového žlábku (křivka 2. 8. 2019). Tento profil má ostré hrany z výroby a hloubka žlábku činí 14 mm. Druhý profil znázorňuje srdcovku před navařením materiálu (křivka 17. 6. 2021). Profil má již zaoblené všechny hrany, přičemž došlo k ojetí křídlovky o $3,8 \mathrm{~mm}$ ve svislém směru. Dále je u tohoto profilu patrné prohloubení žlábku na celkovou hodnotu 21,6 mm. Také je patrný vznik dvojžlábku. Třetí profil znázorňuje již navařenou srdcovku (křivka 30. 7. 2021). Tento profil má hloubku žlábku 14,8 mm. Nicméně během reprofilace žlábku nedošlo k zostření hran a to jak u dna žlábku, tak u křídlovky.

\section{Výtoň - Střed - vybraná data}

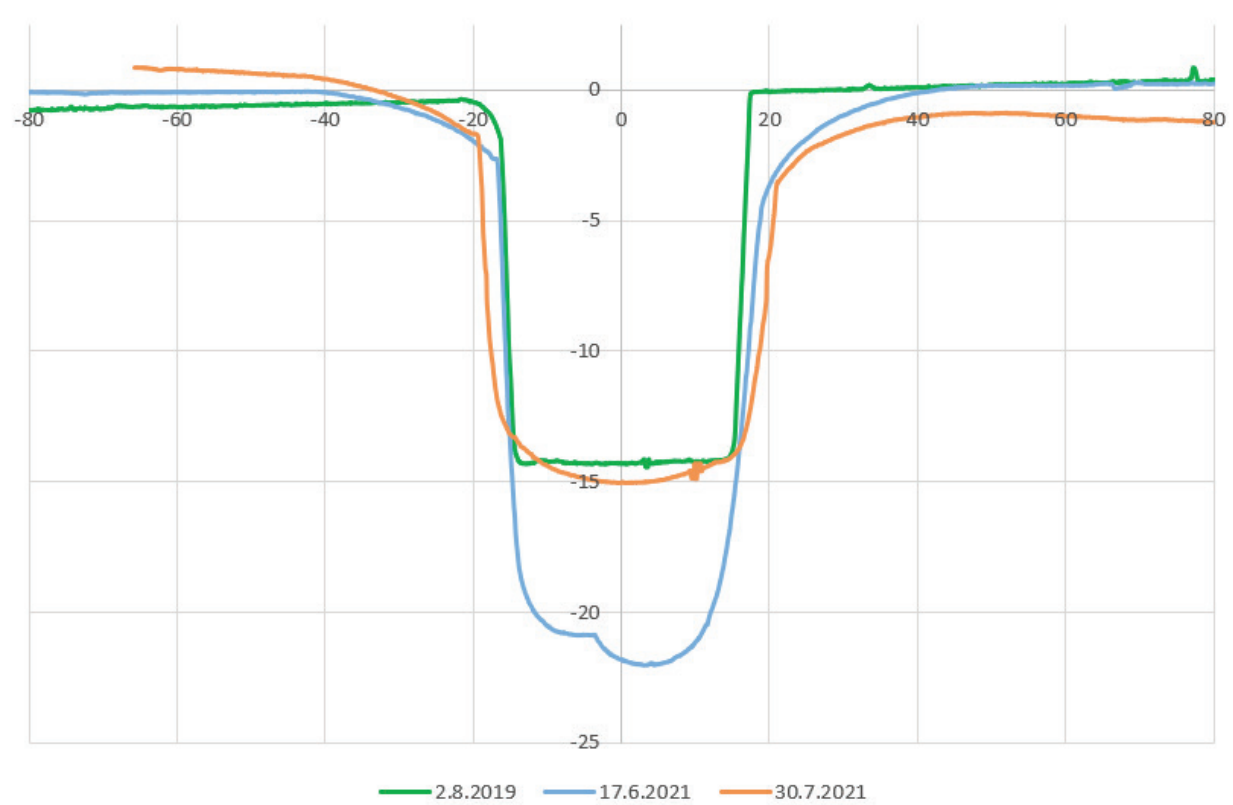

Obr. 5 Vybrané středové profily srdcovky v lokalitě Praha - Výtoň (Zdroj: Autor).

Z průběhu deformací lze také udělat srovnání žlábku nového z výroby a žlábku po údržbě. Tyto dva profily jsou zobrazeny na Obr. 6. Z tohoto obrázku je patrná, že hloubka obou žlábků se pohybuje kolem 14 mm. Hloubka nového žlábku činí přesně $14 \mathrm{~mm}$, což je očekávatelné vzhledem k tomu, že byl žlábek průmyslově vyfrézován a až poté následně zabudován do konstrukce. U navařeného žlábku hloubka činí $15 \mathrm{~mm}$, což je odpovídající s ohledem na technologii navařování, kdy k navaření dochází bez výluky za běžného provozu. Dalším rozdílem je podoba hran žlábku. U nového žlábku jsou hrany ostré. U žlábku navařeného zůstávají vlivem ojíždění zaoblené, a to jak hrany dna žlábku, ale také hrany křídlovky. I tento rozdíl je pravděpodobně způsoben vlivem technologie navařování, nicméně není dále jasné, jaký má tento faktor vliv na další vývoj ojetí a deformací, případně na emise hluku [5]. Poslední rozdíl mezi těmito žlábky je v jejich šířce. Šířka žlábku na povrchu srdcovky činí přibližně $36 \mathrm{~mm}$. U navařeného žlábku činí jeho šířka přibližně $40 \mathrm{~mm}$. Je tedy patrné, že dochází pouze k navaření materiálu na dno žlábku, nikoliv na strany žlábku. 


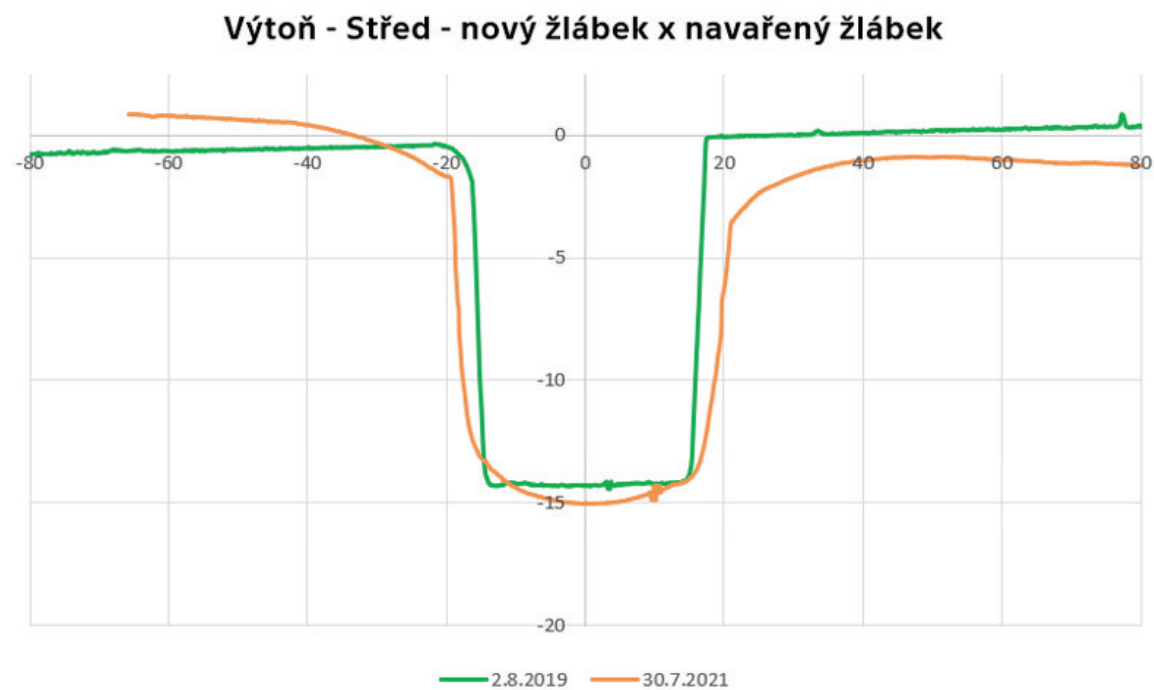

Obr. 6 Porovnání profilu žlábku nové srdcovky se žlábkem po reprofilaci navařením (Zdroj: Autor).

\section{ZÁVĚR}

Z provedených měření je možné vyvodit 2 závěry. První závěr je, že při prohloubení žlábku dochází i k ojetí a deformaci povrchu srdcovky (tzv. kř́dlovky). Druhý závěr, který je pro tento příspěvek stěžejní, jsou rozdíly mezi tvarem žlábku z výroby a tvarem žlábku po navaření srdcovky. Největší rozdíl mezi těmito profily je zaoblení hran žlábku. Tento faktor by mohl mít vliv na dynamiku jízdy vozidla přes srdcovku a následně pro výši emisí hluku oři průjezdu vozidla přes konstrukci. Také z této práce plynou další otázky a to především:

- Jak se bude vyvíjet deformace žlábku po navaření (s ohledem na vývoj deformací nové konstrukce)?

- Jaký vliv má navaření na emise hluku při průjezdu vozidla přes srdcovku?

Proto by v rámci dalšího výzkumu mělo dojít $\mathrm{k}$ dalšímu sledování konstrukce a následnému měření hluku. Tím by se měl určit vliv navaření srdcovky na její další životnost a na výši hluku při průjezdu vozidla přes srdcovku.

\section{Poděkování}

Př́spěvek byl zpracován za podpory projektu TAČR Dlouhodobý monitoring kolejových konstrukcí u tramvajových křižovatek se zaměřením na mělké srdcovky za účelem optimalizace jejich údržby a snížení hluku (číslo projektu TJ04000257).

\section{Použité zdroje}

[1] KŘEČKOVÁ, Magdalena. Monitoring vybraných tramvajových srdcovek. Praha: ČVUT v Praze, Fakulta stavební, Bakalářská práce. 2020.

[2] ZELENKA, Jaromír a Martin KOHOUT. Vztah kolo-kolejnice v podmínkách tramvajového provozu. Plzeň: 46. zasedání odborné skupiny tramvajové tratě, Sdružení dopravních podniků ČR.

[3] PENC, Miroslav. Projekt Kolo-kolejnice. DP-kontakt. Praha: Dopravní podnik hlavního města Prahy, 2010/4, ISSN 1212-6349.

[4] BRET, Ondřej. Akustická analýza průjezdu tramvají přes kolejovou konstrukci odbočení se srdcovkou s mělkým žlábkem. Brno: Juniorstav odborná konference doktorského studia. 2021

[5] BRET, Ondřej. Praktické využití akustické kamery pro sledování kolejových konstrukcí na tramvajových tratích. Znojmo: 100. akustický seminář, Sborník 100 akustický seminář, ISBN 978-80-01-06888-5 